\title{
Inclusivity in the Old Testament
}

\section{Authors:}

Ananda Geyser-Fouche ${ }^{1}$ (C)

Carli Fourie ${ }^{1}$

\section{Affiliations:}

${ }^{1}$ Department of Old

Testament Studies, Faculty of

Theology, University of

Pretoria, South Africa

\section{Research Project Registration:} Project Leader: A.B.

Geyser-Fouche

Project Number: 1258230

\section{Description:}

Carli Fourie is participating in

the research project, 'Second Temple Literature and

Qumran', directed by Dr

Ananda Geyser-Fouche,

Department of Old Testament

Studies, Faculty of Theology,

University of Pretoria.

\section{Corresponding author:}

Ananda Geyser-Fouche, ananda.geyser-fouche@up.

ac.za

\section{Dates:}

Received: 07 Aug. 2017

Accepted: 12 Sept. 2017

Published: 27 Oct. 2017

How to cite this article: Geyser-Fouche, A. \& Fourie, C., 2017, 'Inclusivity in the Old Testament', HTS

Teologiese Studies/ Theological Studies 73(4),

a4761. https://doi.org/

10.4102/hts.v73i4.4761

\section{Copyright:}

(C) 2017. The Authors.

Licensee: AOSIS. This work

is licensed under the

Creative Commons

Attribution License.

\section{Read online:}

Scan this QR
code with your
smart phone or
mobile device
to read online.

In this article, the concept of inclusivity in the Old Testament is investigated and the theology of 'Otherness' is discussed broadly. Various authors discuss the 'Otherness' in biblical Israel. These views are critiqued and a conclusion is reached that an inclusive reading in the Old Testament, specifically of the known exclusive texts in the Hebrew Bible, is a possibility. To argue for inclusivity in the Old Testament, a view of hospitality is considered and a literary review of inclusive texts is conducted, namely the Books of Ruth, Jonah, Ecclesiastes, Esther and some Deuterocanonical texts.

\section{Introduction}

Over decades researchers have looked upon the chosen people of God, the Israelites, as an exclusive community, where there are little or no space for foreigners or outside communities. ${ }^{1}$ Van Wyk (2017:1) took an interest in Miroslav Volf's theology in the light of the one hundred year celebration of the Faculty of Theology at the University of Pretoria. The focus was on the metaphor, 'opening of the gates' as an open invitation to all peoples across race, culture, ethnicity, etc. (see Faculty of Theology 2017). Van Wyk emphasised the tension between inclusivity (to embrace) and exclusivity (to exclude) in general, and consequently quoted Miroslav Volf (Van Wyk 2017):

An embrace involves always a double movement of opening and closing. I open my arms to create space in myself for the other. The open arms are a sign of discontent at being myself only and of desire to include the other. They are an invitation to the others to come in and feel at home with me, to belong to me. In an embrace, I also close my arms around the others - not tightly, so as to crush and assimilate them forcefully into myself, for that would not be an embrace, but a concealed power-act of exclusion; but gently - so as to tell them that I do not want to be without them in their otherness. I want them to remain independent and true to their genuine selves, to maintain their identity and as such become part of me so that they can enrich me with what they have and I do not. (p. 1)

This quote is cited strategically in this study in the light of the exclusive language which appears in the Old Testament, whereas inclusive language in Israelite history is rarely noted. Exclusive language used by different researchers (only some will be noted) is: 'stranger' (Martin 2014:2); 'sojourner, resident alien' (Clines 2009:70); 'foreigner' (especially in marriages) (De Villiers \& Le Roux 2016:3; cf. Ben Zvi \& Edelman 2014:14; Harlow et al. 2011:106); and the most popular language is 'other' or 'otherness' (Clines 2009; Geyser-Fouché 2016:3; Harlow et al. 2011). On the other hand, inclusive language is rarely seen in the Old Testament and as Geyser-Fouché (2016:2) notes also with regard to exclusive language, it is 'not always uttered speech or of an emphatic nature but can also lie in what has not been said'. And like in the Book of Ruth, it lies in language that has been left out, like De Villiers and Le Roux (2016) note:

One can almost say that the authors of the inclusive texts purposefully chose to avoid the characteristic 'jargon' of the exclusive texts - that is, 'book', 'Torah', or 'as it is written' in either the 'book' or the 'law'. (p. 3) ${ }^{2}$

In this study, various viewpoints will be assessed on the subject of inclusivity in the Old Testament. Inclusivity is seen as the inclusion of the 'other', which can be seen as an inclusion of all in such a broad term as referring to the whole creation - not just everyone, but also everything. Radical inclusivity is also global justice. In this study, however, albeit mentioning the broad concept of inclusivity, the focus will be more on how inclusivity is found in the Israelite culture as portrayed in the Old Testament of the Hebrew Bible. It will be argued that inclusivity in the Old Testament is a possibility - that there is also a definite 'inclusive dimension' in (some) Old Testament texts, as compared to its strongly emphasised 'exclusivity'. A focus on a 'theology of Otherness' is therefore the aim to highlight this inclusivity.

1.Israel's exclusivity brings questions upon the Old Testament's relevance today, and in Loader's words 'being a failure' (see Loader 2014 cf. Meyer 2011). Thus, this subject of inclusivity in the Old Testament is relevant.

2.De Villiers and Le Roux (2016:3) argue a very interesting point where the author of Ruth chose a specific historical time 'the time of the judges', which strategically sidesteps the jargon of the exclusivist circles of the priestly terminology used in the postexilic Second Temple period. This argument will be discussed later in this study. 
This article is written in honour of Yolanda Dreyer, which will be incorporated into the honorary corpus of her 'Festschrift'. Yolanda Dreyer is one of the ambassadors of inclusivity and wrote studies on various subjects, amongst others: 'homophobia' (Le Roux \& Dreyer 2013); feministic articles on how women are marginalised (Botha \& Dreyer 2013; Dreyer 2011). Amongst her colleagues, Dreyer vowed for ecumenical unity in the church (Nederduitsch Hervormde Kerk van Afrika 2017) and disregarded the dominant positive opinion of apartheid in South Africa's history (TEO 2009). In short, Yolanda Dreyer stood up for the modern-day diaspora in person as a professor at the University of Pretoria, as a reverend in the NHKA, and in writing. Thus, that is why the topic of inclusivity is deemed fit, and Volf's quote seems relevant to Dreyer as an ambassador of inclusivity.

In this study, the theology of 'Otherness' will be discussed broadly. Harlow et al. (2011) and Ben Zvi and Edelman (2014) name various authors who discuss the 'Otherness' in biblical Israel. Consequently, these views will be critiqued and a conclusion will be reached that an inclusive reading in the Old Testament and more specifically of the known exclusive texts in the Hebrew Bible is a possibility. To argue for inclusivity in the Old Testament, a view of hospitality ${ }^{3}$ will be considered and a literary review of inclusive texts will be conducted, namely the Books of Ruth, Jonah, Ecclesiastes, Esther and some deuterocanonical texts. The Book of Ruth will be discussed in more detail to argue for a Davidic bloodline through Ruth, the Moabite, who was a foreigner and most probably David's great grandmother.

The Book of Ruth offers an argument for inclusivity in Israel in the Old Testament. Israel's universal exclusivity was mostly about the preservation of Israelite identity. Inclusive Old Testament texts protest against the universal exclusivity of Israelite identity. Thus, the following question: what is Israelite identity?

\section{Israelite identity}

De Villiers and Le Roux (2016:2) and Martin (2014:3) connect the identity of Israel predominantly to religion. Middlemas (2011:119) says that it is paramount to take note of the religious observance in inclusive texts: she calls it the 'behavioural component'. De Villiers and Le Roux (2016) note the precondition of being 'Israel' is to be a community that worships YHWH. De Villiers and Le Roux (2016:2) argue for the Book of Ruth being written in the post-exilic period. They note that after the exile, when the Judaeans were granted the right to return to their previous origins/land, different groups of 'Israelites' lived in various regions in the vast Persian empire. This complicated the identity of 'Israel' because they were no longer a homogenous group.

Firstly, in Yehud there were 'Israelites' who did not experience the exile; they were seen as a different group, yet they called themselves 'Israel'. Secondly, there were the descendants of those who were taken into exile, the returnees to the land,

3.See Martin (2014) in this regard. who were called the 'golah'. With regard to this group, De Villiers and Le Roux (2016:2) note: 'The term "Israel" became reserved for one group only within a number of people who all considered them as part of "Israel"'. The 'golah' believed they were the true Israel and the chosen people of God. This group also consisted of a 'golah elite' who were composed of priests and lay people, and they had a great influence on the people of 'Israel' in Yehud in the post-exilic period. These different groups all of whom considered themselves to be 'Israel' make it very difficult to pinpoint Israel's identity, and consequently, identity cannot be argued as an object which is static and universal.

The author of the Book of Ruth imagined 'Israel' as a group that included outcasts and foreigners. However, to be a part of this community, they had to worship YHWH, the God of Israel. De Villiers and Le Roux (2016:3) assume that the author of the Book of Ruth tried to argue for the survival of Israel's identity and Israel's religion within the foreign Empire by accepting foreigners, thus conforming to the situation and environment. This, however, was a threat to Israelite identity in the sense of threatening pure ethnicity as it becomes evident in exclusive texts like Ezra-Nehemiah. ${ }^{4}$ Moreover, in determining their identity, the temple and God's law became important in their religious lives - even more than before the exile (Boshoff, Scheffler \& Spangenberg 2006:186). The fear of marrying foreign and forbidden women becomes clear in Joshua 23:7-12, namely that it will lead to apostasy, turning away from $\mathrm{YHWH}$, worshipping other gods, and eventually they will lose the land (see De Villiers and Le Roux 2016:4). In return, Ezra (6:21) preconditions a religious and cultural aspect (Brett 2014:89). Through Nehemiah (see Neh 13:1-9, 23-31), it becomes clear that Israel had a fear of being internally sinful and disappointing YHWH, thus driving the 'foreigner' out was a way of projecting this religious fear (Cataldo 2014:14). In such an exclusivist account, the importance of religion in Israel's identity is evident.

\section{Hospitality}

In the Old Testament, hospitality to the 'other' is found as rare as inclusion of the 'other'. Largen (2010:433-439) notes the difficulties of hospitality: 'the practice of hospitality is extraordinary difficult, as at every turn our egos, our tempers, and our self-righteousness get in the way of our genuine openness to another'. Although texts of hospitality are not often encountered or explicitly spelled out, these texts are worth noting in this study of inclusivity in the Old Testament. Genesis 18:1-16 is the first noted text of hospitality, where Abraham sees three unidentified men. Abraham treats them with hospitality, but then for a limited time and with limited resources. Hospitality was normally limited to three days and no longer (Hobbs 2001:21). Abraham opened his home to strangers, who could pose a great danger, as Kooy (1962:654) notes that 'public inns were a rarity and every stranger was

4.See Deuteronomy $7: 1-7$. In Judges 3:5-6, they are indicted for living amongst the Canaanites, intermarrying with them and for worshipping their gods (Martin 2014:3) 
a potential enemy'. Abraham took a chance and changed the status quo: 'Unexpectedly, the strangers become a harbinger of divine abundance' (Reynolds 2006:191-202). He treats them with respect, and according to the laws of hospitality, there was 'numinous reciprocity' (Koenig 1992:299-301).

There are more texts bearing testimony to hospitality: Genesis 19:1-11, 24:15-61, 29:1-11; 1 Kings 17:8-24; Exodus 2:15-22; Judges 19; 1 Samuel 25; 2 Samuel 12; 1 Kings 17:8-16 and 2 Kings 4 . In most cases of inhospitality, there is a lurking fear for the difference between us and others. As Martin (2014:6) notes, 'these differences create barriers to understanding and the lack of understanding inhibits the forging of relationships'.

Consequently, the next point in this study is the theology of 'Otherness' in the Old Testament, which will address a number of subjects regarding exclusivity and inclusivity, as well as inhospitality and hospitality. The next section will also indicate that Old Testament texts are not static; neither in theologies nor in the reception or understanding of the texts.

\section{'Otherness' and the Book of Ruth}

The definition of Otherness is described in Cataldo (2014):

The structure of the Other is an interiorization of difference - I am 'black', 'female', and 'gay' because I am not 'white', 'male', and 'straight'. It is, to employ a biblical example 'people of the land' actively and self-referentially defining themselves as distinct, different, or foreign, based on the qualities projected upon them by the golah community. I am ' $x x^{\prime}$ because I am not ' $x y^{\prime}$, which are qualities found in the margins of power, projected upon them ... (p. 6)

Or Edelman (2014) who defines 'Othering'5 as follows:

Othering is a psychological strategy for establishing and reinforcing individual or group identity through separation and the establishment of boundaries of difference. It is part of human nature to want to feel unique or special in some way, and Othering is a necessary process to use to set oneself or one's group apart so that the individual or the group can be assigned one or more unique characteristics. (p. 41)

Edelman (2014:42, 43; cf. Berge 2014:76) importantly notes that Israel is a collectivist culture, and the characteristics of this culture are association, super-ordination, intimacy, overtness, cooperation, inequality, informality, security, restricted conformity, traditionalism and benevolence. Grouplinked memories, the preservation of community-bound identity and especially the bond to YHWH are most important. This culture determined the way Israel treated people from the outside. The collective construct is of an 'Other' as the 'not-Us' over against whom 'We know ourselves as Us' (Camp 2014:106; cf. Walsh 2014:126).

Nowadays, interpreters are hermeneutically well aware that by reading the biblical text we cannot get away from our presuppositions. Cataldo (2014:2) notes: 'And our readings

5.The verb form of the word 'other' is already a good strategic naming of this universal phenomenon in Old Testament texts. Othering is most certainly a verb and fits this character, by doing something to someone. of the biblical texts can really only hope to reconstruct the Other through interpretations of this Other by the authors who assume dominant positions over her' ${ }^{6}{ }^{6}$ In this instance, it is important to be careful of presuppositions in the subject of universal exclusivity or inclusivity. In this regard, De Villiers and Le Roux (2016:4) state that although the Book of Ruth can be seen as an inclusive text, it can be in no way interpreted as proposing a universal inclusivity for foreigners as the book is very clear with regard to its most important interests, which are the identity of Israel and the worship of YHWH (De Villiers \& Le Roux 2016:4). This study wants to portray the complexity of exclusivity and inclusivity in Old Testament texts.

In the instances where homogenous Israel excluded the outsiders who were perceived as the 'Other', it became dehumanising $^{7}$ and the issue became relational - and therefore the 'Otherness' is so broadly discussed (cf. Howes 2014:2). ${ }^{8}$ The 'Other' is engaged by 'us' as an external object through which the 'us' legitimises its power systems. This 'us' is understood as anyone who excludes the 'other'; in this study, it is 'Israel' who excludes as a homogenous group. The relationship pattern on this objectification is between an individual and 'his/her' object. This object relationship also categorises experience by internalising what is pleasing and externalising what is uncomfortable and threatening (Klein 2011:5). Through this process, the individual and society become structured. The more complex societies become, the more complex the perception of 'good' and 'bad' towards the object becomes. In this complexity, it seems plausible that the Israelites blamed those who were not exiled; thus, in cases like that seen in Ezra-Nehemiah, the 'Israelites' who were not part of the golah were also 'otherised' (Cataldo 2014:12, 13).

In response, Touraine (2007:189) accounts that the 'Other's' productivity is limited by social regulations; thus, there is no place in society for the 'Other'. The 'Other' is identified as an object of the external dominant order. The 'Other' can only act in reference to the subject - which emphasises an inhuman dimension. This power of regulating the 'Other' was granted by the Persian Empire who allowed the 'golah elite' to govern the Yehud area (De Villiers \& Le Roux 2016:1-2). The power that the 'golah elite' had brought unnecessary friction.

The point of this information is to give credit to this complex system and to recognise that these differences between object-subject are continually defining and redefining. Zizek (2008:12) notes, 'The Other is not a static or permanent category but the cause of our response'. Kaminsky (2011:22) notes that it is important not to systematise these variant images of Israel and 'Otherness' for these societies were complex. A view on this complexity is Kaminsky's (2011:22) argument that there are many texts that view the 'Other' in

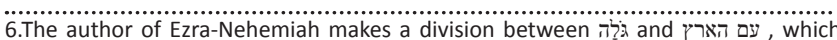
takes a socio-political dominant position ('Golah' against the 'people of the land') (Cataldo 2014:3, 6).

7.See also Cataldo (2014:15) - There is an emphasis on an inhuman dimension, the Other only acts in reference to the subject.

8.'Like most Jewish writings, a clear line is, firstly, drawn between Israel and the gentiles'. 
a neutral or positive way, and some include selected foreigners within Israel's cultic life, to imagine a time where all nations will worship YHWH.

Zizek (2008) reminds us that the theology of 'Other' is influenced by the presupposition of socio-politics. Being in a relation is self-referential and behind that exist egocentric and narcissistic actions. Zizek (2008:12) notes:

Since the Bible is a cultural artefact, what this means for studies of the biblical text and, specifically, of the Other in the Bible, is that there is no factual Other in the biblical text. Any attempts to reconstruct the objective identity of the Other are entirely fantastical. (p. 12)

This fantastical 'Other' is legitimised by historical criticism, where the important emphasis is on time, place and circumstances, which draw forth the real agenda of the writing of the text. This approach uncovers the political interests of the writers, users and canonisers who relied on the biblical text to suppress alternatives that threatened their own supremacy (Keck 1996:130-141). As Zizek (2008:12) notes, it is important to recognise the processes that shape interrelationships in a social setting and between subject and object.

Accordingly, it is also important to notice the underlying powers in the biblical texts. Clifford (2009:121) argues for a social study of the Bible and remarks that there was a literary turn in cultural analysis, but there was also a cultural turn, not only in social science but in biblical studies as well'. Hereby Clifford (2009:121) sees the importance in the underlying power through the cultural interpretation of the biblical text and concludes that it is 'a hierarchical structure of powerful stories that translate, encounter, and recontextualize other powerful stories'. A good example is the Deuteronomistic tradition where there is a lack of references to the relational aspect of Israel with the 'Other', but it seems that the Deuteronomist had an interest in the Torah and Moses, and this scroll should be studied, recited and taught (Berge 2014:85). Given the lack of relational writing, it seems that the Deuteronomist wrote this text outside the land (possibly from Babylon). The implication is in summary that the Pentateuch's presentation of the relation between the Israelites and the 'Other' cannot be seen as a practice of 'categorical identities' (Berge 2014:88). In answer, Berge (2014) notes:

When discussing the Pentateuch and social identity formation in Yehud, one should note that the authors who wrote about the Canaanites were very much aware that this group of people belonged to the ancient past, not to the present. One should also keep in mind that these later redactors and authors included the previous narrative layers of the Pentateuch, which tell about a very complex and 'living' relationship between the Israelite ancestors and the Other peoples, including those in the Land, in some instances also letting their representatives, as individual subjects, speak for themselves. As interpreter and commentators on the biblical view of the Others and its ethical implications, we are morally required to present this full and complex picture. (p. 88)

\section{The infinitely Other}

Levinas (1989:121-129) exemplifies YHWH as the 'infinitely Other' because YHWH is unsusceptible to change. The 'infinitely Other' is a 'Being' whom you just let be, and who was always there unchanged. Rather than excluding, Israel should come face to face with this 'Being', establish a relationship, and face to face Israel will discover its real identity. By this 'Being' we are judged and called into an ethical relationship (cf. Römer 2013:1-5). Ironically, the 'infinitely Other' is also an 'Other' who brings forth a new understanding of social behaviour. Zizek (2008:31) explains it as follows: 'The Other, therefore, is known on account of our responsibility and response to the Other and our judgement by the Other, through which we become responsible to the Other'.

Thus, as Levinas (1989:121-129) notes, reason and freedom are not independent but founded on prior structures like the 'Other' and that freedom is not justified by itself, but by and for the other. This also has a selfish implication, where the naturalists even note that nature is 'Otherized' (see Gn 9:2). John Muir (1997:589-606) responds: 'I have never happened upon a trace of evidence that seemed to show that any one animal was ever made for another as it was made for itself'. And even when humans cry, the cry is about themselves, as Heihachiro (see Blyth 1949:78) the poet writes: 'Even the broken grass, or the fallen tree, or the cut stone gives us sorrow, because we feel they are in our minds'.

Ben Zvi (2014:27) notes that in the time of the reign of the Northern Kingdom (as seen in $1 \mathrm{Ki}$ ), faith was important for being an Israelite. However, there were times that seem like grey areas when Israel 'Otherised' themselves and where the 'Other' did not have to be imagined in the remembered community to be part of Israel. Jezebel (see $1 \mathrm{Ki} 17: 31$ ), the Sidonian woman and Queen of the Northern Kingdom, persecuted the prophets of $\mathrm{YHWH}$, yet another Sidonian woman acknowledged YHWH and his prophets. Thus, the Israelite elite is 'Otherised' and the other Sidonian woman (a non-Israelite) is 'Israelitised'. Thus, it appears that communities and specifically the Israelite community were constantly reformulating and changing - each context matters and constantly differs from other contexts (Ben Zvi 2014:27).

When it comes to the 'infinitely Other', it seems that there was a possibility that the 'Other' might become part of Israel, on the condition of having a relationship with $\mathrm{YHWH}$ (cf. Heckl 2013:2). ${ }^{9}$

If Israel's identity is determined by being in relation with $\mathrm{YHWH}$, and if 'Others' are in dialogue with $\mathrm{YHWH}$, the implication is that outsiders may become insiders. Job serves as a good example: he is introduced as a man from the land Uz, a non-Israelite who was in direct dialogue with $\mathrm{YHWH}$ and whose discourse formed part of Israelite discourse. Another similar case is presented by the relations 9.'It aims at the acclamation of the people to serve YнWH alone'. 
of Esther/Mordecai against Haman/Ahasuerus. ${ }^{10}$ In the case of Esther: although there are 'Otherised' figures, like Esther as a woman and Ahasuerus the non-Israelite Persian King, Israel had to put their trust into these 'Others' for the survival of Israelite history (Ben Zvi 2014:27-33).

To conclude in favour of Levinas (1989:121-129), the 'infinitely Other' appears to be unchangeable, but there was an inclination in Israelite history to anthropomorphise the divine - to assign human attributes to YHWH. For example, Israel 'Israelitised' YHWH with the principle of imitatio Dei (e.g. Lv 19:2) and imago Dei (e.g. Hs 2:21 [19]; Is 60:3) (Ben Zvi 2014:40). In contrast to Israel using this principle to exclude, the concept of imago Dei can also be argued of being in favour of inclusivity (cf. Martin 2014:1-9). Israel used the covenant between them and $\mathrm{YHWH}$ as a matter of excluding, ${ }^{11}$ but the principal of imago Dei provides another insight.

Martin (2014:8) concludes that there are four commonalities between humans, which are found in the Old Testament: (1) all humans bear the image of $\mathrm{YHWH}$; (2) all humans are relational creatures; (3) all humans are dependent upon each other and (4) all humans are travellers hosted by YHWH. 'So God created the man (human) in God's own image ... male and female God created them' (Gn 1:26).

Not all Martin's commonalities will be discussed, but only the imago Dei and humans as travellers hosted by YHWH. Through the imago Dei, as humans, we share common humanity and this is enough reason for universal hospitality but which is not always appreciated and also not always lived within Israel. Secondly, Ogletree (1985:3) notes that the Old Testament suggests that all humans are travellers, strangers in an alien land. 'We are all sojourners', as seen in Leviticus 24:23 and Psalm 24:1 (cf. Ex 9:29): 'Earth is the Lord's, and all it contains, the world, and those who dwell in it'. YHWH extended that hospitality to Israel when they travelled through the wilderness (Ex 16-17), but He did not stop at Israel - YHWH welcomed all of humanity, the animals and even the plants (Ps 104:10-21). Reynolds (2006) explains:

As the covenanted people of God were themselves aliens, and remain vulnerable sojourners with God, provided for and loved by God (Leviticus 25:23), so too they should love others ... All human beings are strangers in one sense or another. (pp. 191-202)

YHWH reminded Israel of this in Leviticus 25:23: 'The land is mine; you are sojourners'. Martin (2014) refers to Isaiah 25:6-8 saying that this is realised within the eschatology and YHWH's eschatological hospitality:

And the Lord of hosts will prepare a lavish banquet for all peoples on this mountain ... And on this mountain he will 10.See the biblical text of Esther (cf. Ex 17:14-16; Dt 25:17-19; 1 Sm 15; 28:18).

11.This covenant language used is seen in many texts: Psalm 41:14; $106: 48 ; 81: 11$ 94:23; 20:8; 99:5; 105:7; 106:47; 113:5; 122:9; 7:2; 18:29; 30:3; 31:15; 35:24 104:1; 109:26; $140: 7 ; 144: 15 ; 146: 5 ; 68: 21 ; 140 ; 8 ; 8: 2,10 ; 1$; $104: 1 ; 109: 26 ; 140: 7 ; 144: 15 ; 146: 5 ; 68: 21 ; 140: 8 ; 8: 2,10 ;$ Isaiah 45:3; 41:13; 43:3 48:17; Malaquias 2:16; Zephaniah 2:9; 3:17; 2:7; 3:15; Hosea 3:5; 7:10; $12: 9 ; 13: 4$ 14:1; Joel 1:13; 2:13-14; 26-27; Amos 9:15; 17:8; 4:2; 5:3; 6:8; 8:1; Micah 7:10 4:5; 7:17; Zechariah 6:25; 11:4; 14:5; 9:16; 10:6; 2:14; Habakkuk 1:12; 3:19; Hagga 1:12; Obadiah 1-2; Genesis 23:26; 28:15; 31:3; 48:21; 28:20; 31:5; 35:3; 26:24; Exodus 33:16; 33:5; Ezekial 34:30; Joshua 22:31; 3:10; Numbers 11:20; Joel 2:27. swallow up the covering which is all peoples, even the veil which is stretched over all nations. He will swallow up death for all time, and the Lord God will wipe away the tears from all faces. (p. 8)

Martin (2014:8) compares YHWH to a host and reveals that the 'infinitely Other' is hospitable towards us, the sojourners or the 'Others'. Levinas (1989) further explains:

... that the Other is not which is opposite to me but rather as that which is separate from me, that which is radically exterior to me, that which is utterly transcendent, exceeding me. The encounter with the Other makes me aware that the world is not simply my possession or an extension of me, but that I share the world. (pp. 121-129)

Edelman (2014:26-69) explains that in texts where covenant language is used (cf. footnote 19):

the relationship between the deity and Israel is portrayed as follows: Israel as YHWH's garden; Israel as $\mathrm{YHWH}^{\prime}$ flock; Israel as YHWH's covenantal son. The language that is used in these texts shows a deep collective mentality, where there is a fear of losing this relationship with the deity, which is integral to their identity. Their identity as the covenantal people of $\mathrm{YHWH}$ (e.g. Lv 26:44; Ps 111:9; Is 41:8-10; Jr 31:35-37; 33:23-36; Hs 1-2) is emphasised by portraying them as 'set apart'. There were times that this fear was realised and the relationship was temporarily suspended (e.g. Lv 26:44; Ps 111:9; Is 41:8-10; Jr 31:35-37; 33: 23-36; Hs 1-2) and times where $\mathrm{YHWH}$ as the universal deity in control of creation and all the earth's inhabitants expanded his family to include other people and nations (Am 9:7; Zch 11:10).

According to the principle of imago Dei and YHWH as host, it seems possible that $\mathrm{YHWH}$ as the 'infinitely Other' displays an openness towards the inclusion of the 'Other' in the Old Testament.

\section{Ruth the Moabite}

Kaminsky (2011) asks this question:

Why is it that in personal psychology we tend to accept the notion that through deepening one's own unique self a person matures and comes to interact with others in an ever more sympathetic fashion, but in social psychology we too easily assent to the opposite belief, that only by weakening our unique national and ethnic identities can we ever hope to understand and respect the Other? (p. 30)

In response, the Book of Ruth gives new insight that Israel didn't give away their unique identity by being inclusive. The Book of Ruth is the most common inclusive text and in general claimed in the perspective of inclusivity. Some scholars have dismissed the use of Ruth as foreigner who was accepted into the Israelite community (cf. Lim 2011:101-115) but most have argued for Ruth's inclusivity.

Lim (2011:107) argues that the author of the Book of Ruth expresses her foreignness in every possible way. She (Lim 2011:107) notes that 'Ruth the Moabite' is mentioned five times in three chapters $(1: 22 ; 2: 2,21 ; 4: 5,10 ; 2: 10$; cf. Walsh 2014:133). Lim (2011:101-115) asks why this might be - and her answer is that the author wants to underscore the foreign 
origins of Ruth. She also remarks that the author prominently writes about the language mistake Ruth makes, which was common amongst those who were bilingual. The mistake Ruth makes is to use the word (נערים) instead of (נָערוֹת) and in the text, Naomi corrects her in 2:23. Then Lim (2011:115) concludes: 'Both her character and speech are literary creations, and my contention is that the author has exploited what he knew about non-native speakers of Hebrew to underscore the foreignness of Ruth "the Moabite"'. Lim (2011:115) concludes this in a negative sense. However, many scholars would disagree in this regard and rather underline that the author used Ruth's foreignness to portray Israel's inclusivity, which in fact led to an extended genealogy.

De Villiers and Le Roux (2016:1-6) argue for inclusivity and start by pointing out the first verse of the biblical Book of Ruth (Rt 1:1): 'In the days that the judges judged ...' According to De Villiers and Le Roux (2016:1; cf. Cohn 2014:18012), the Book of Ruth is written as a narrative critique against the community law of Dt 23:3-4 [2-3] - and the setting in the historical period of the judges thus functions as a literary device (cf. De Villiers 2013:1-8). It is important to note that the author of the Book of Ruth does not want to undermine the authority of the Torah (De Villiers \& Le Roux 2016:3). This book must have been written in the post-exilic period, but the author chose the historical time of the Judges in order to sidestep the 'jargon' of the exclusivist circles. ${ }^{13}$ Typical exclusivist 'jargon' as employed by Ezra-Nehemiah are words like 'Torah', 'book' or 'as is written', and these words are completely avoided in the Book of Ruth. De Villiers and Le Roux (2016:3), on the other hand, argue that inclusivity is definitely prominent in the Book of Ruth.

The issue of exclusivity is Ruth's foreignness and the problem of foreign marriages in post-exilic Judah (Yehud) - as attested by the authors of Ezra-Nehemiah. In Joshua 23:7-12, Joshua warns the children of Israel not to mix with the people of the land, which will lead them to turn away from YHWH. Thus, again the issue is directly linked to Israel's identity - the religious factor, Israel's covenantal unique 'Otherness'. The literary function of the Book of Ruth bypasses the 'current' status quo of Ezra-Nehemiah, thus the Priestly terminology. If this is the case, this Book is written in an ingenious way within the historical time to avoid this exclusive ideology of the exclusivists.

There are however texts that were more positive towards Moab - for example, Deuteronomy 2:27-29, where the Moabites were willing to sell water and food to the Israelites. The implication of the inclusivity of Ruth may lead to the inauguration of an eschatological future ('messianic' future of David; cf. Cohn 2014:171). ${ }^{14}$ In this case, one can even

12.The tight links between Ruth and Deuteronomy suggest that Ruth represents an alternative tradition showing how the spirit of family redemption in the levirate law could be embodied in a human inclusive way (p. 180).

13.Postexilic terminology was influenced by Priestly terminology (see De Villiers \& Le Roux 2016)

14.If Ruth's female identity is finally swallowed by the male family tree, it is also the case that Ruth's arrival in Bethlehem widens Israelite identity by making possible the continuation of the Genesis family line leading to David the king (p. 171). argue that the author argued for the survival of Israel and Israel's religion within the foreign empire (De Villiers \& Le Roux 2016:3). De Villiers and Le Roux (2016:5; cf. Cohn 2014:164 ${ }^{15}$ ) conclude that the Book of Ruth was written to correct the negative image of Moabites (and foreigners) during the post-exilic period. However, this view is in direct contrast to Lim's (2011:115) argument.

Wetter (2014:144) also argues for Ruth's inclusivity but through an ethnic approach. This approach includes ethnic like language, religion, certain customs and most importantly, kinship. With this approach, Wetter (2014:146) notes: 'Human beings are born not only into a nuclear family but just as much into wider social and perceived kinship relations, with a particular language, religion and a set of customs'. Wetter argues that Ruth's identity becomes re-inscribed within the Israelite identity, and Ruth travels in time and space to be reimagined within the Israelite community. Like Lim, Wetter (2014:151) considers the word for 'stranger' (נְכְְר) and (גוּרי) as 'sojourner' to assess how Ruth was included into the Israelite community and how she was accepted after winning the trust of Boaz by being loyal to Naomi. Wetter (2014:151) refers to Numbers 15:16 as a possibility to accept 'strangers' into the Israelite community: 'One law and one rule shall be for you and for the sojourner who sojourns with you'. Ruth also had a desire to be accepted into Boaz's clan by using submissive language (נָכְְרי) (Wetter 2014:153). This acceptance had consequences. Wetter (2014:153) compares Ruth to Rachel and Leah (Gn 31:15) who had to become 'strangers' to their father before they could be accepted (as foremothers) in Israel. This was also the case with Ruth, and it is by this action that she won her trust in this clan.

Another important word which is used for Ruth's commitment towards Naomi and towards YHWH is the word hesed [love] in Ruth 1:8. This word has a direct transcendental relation towards the 'infinitely Other' as Glueck (1927) notes:

Hesed does not consist of correct sacrificial practices or outward piety, but rather of moral-religious conduct, of the devoted fulfilment of the divine ethical commandments. In that sense, there is no difference between hesed as inter-human practice and hesed of humans towards God. (p. 23)

This is directly connected to Israelite identity and the one important principal Ruth followed. By Ruth's pledge of loyalty, the elders accepted Ruth into the community, as seen in Ruth 4:11-12. Hereby the concept of 'us' versus 'them' is deconstructed and filled with new meaning (Wetter 2014:160). Becoming an Israelite and being accepted in Israel, at that time, was infinitely more important than remaining a Moabite. Ruth's inclusion condensed Israel's identity more in the form of a religious identity than a genealogical identity (Wetter 2014:161).

Cohn (2014:163) also believes that the Book of Ruth, in a time where 'mixed marriages' posed a critical problem for

15.The book of Ruth offers not only a different perspective on the time of the judges but also a new narrative of Israelite-Moabite relations within which to position postexilic Jewish identity (p. 164) 
the small and struggling community in Yehud in the postexilic period, has a message of inclusivity. Cohn (2014:164) studied anthropologists' views regarding Israelite identity, like those of Stuart Hall (1990:222-237). Hall (1990:222-237) denounces Israel's cultural identity, by saying that it is processual rather than essential. Hall (1990:225) notes, 'that cultural identities are constantly in flux, subject to the continuous play of history, culture, and power'. In effect, religious identity becomes more important. ${ }^{16}$ In the Book of Ruth (cf. Is 56-66) it is possible to join YHWH's people as an 'Other'. Cohn (2014:175) concludes in an argument that 'within this androcentric environment, Ruth steps forth and is recognised as a woman of substance'. And, 'In my terms, by offering a counter history, a tale of union rather than dissolution, the book provides a fresh basis for legitimating an inclusive post-exilic Jewish identity (Cohn 2014:175)'. Boshoff et al. (2006:192) also notes a positive approach from YHWH's side, where YHWH can create a new future for his people, through the goodwill and devotion of a 'foreigner'. Boshoff et al. (2006:192) argue that the role of the Book of Ruth and the 'Other' mark a 'significant shift in social memory' and signify a 'rewrite of the sacred history to include the formerly detested Moabite within the lineage of the great King David himself'.

In the beginning of this section, we quote Kaminsky's (2011:30) question with regard to why it is necessary to weaken one's unique national and ethnic identities in order to understand and respect the Other. We can refer to Walsh's (2014) conclusion to add inclusio to this question that it was not necessary for Israel to abandon its identity to be inclusive:

Ruth, then, though Other by ethnicity and gender, is not a woman on the edge for long and does not use her position to challenge, still less critique, the power structure of Israel. Instead, the narrators use her to serve their ideological agenda for the inclusion of foreigners. They advance that inclusion by receiving Ruth's foreignness and construing her womanhood to male conventions of utility to Israel. (p. 135)

\section{More inclusive texts}

De Villiers and Le Roux (2016:2) indicate more inclusive texts from the post-exilic period: the Book of Jonah; the Book of Judith; passages from Isaiah 56:1-8; Esther; and Ecclesiastes. De Villiers and Le Roux (2016:3) note that Isaiah 56:1-8 welcomes foreigners into the YHWH community. Kaminsky (2011:19) also highlights Isaiah 56 as an inclusive text, but adds Ezekiel 40-48, Ezra 6:2117 and Nehemiah 10:2918 to the inclusive corpus. Kaminsky (2011) notes:

In fact, the closest thing to an actual conversion ceremony within the Hebrew Bible might be found in Exodus 12:48-49,

16.Cohn (2014:167): 'For Deutero-Isaiah, and ultimately for Ruth as well, religious loyalty trumps ethnic difference'.

17.In this regard, I do not agree with Kaminsky. I am of the opinion that the 'Other' in this text refers to the Israelites who stayed in Israel and were not taken into exile In other words, this text indicates that all of those that returned from exile, as we as the ones who stayed behind, kept themselves pure and followed the expected guidelines at Passover.

18.I am also of opinion that this text that Kaminsky is referring to refers to the same 'other' that we find in Ezra. It is not other nations, but actually, the ones who practiced exclusivism. often viewed as a late $\mathrm{P}$ passage, which permits an alien who is willing to be circumcised along with the males in his family to participate in the Passover ritual. (p. 19)

This conversion gave 'strangers' the chance of being included into the community of Israel and the family of YHWH. This inclusion was on the basis of conforming to the Passover ritual. Thus, the inclusion was not free of bias, but it indicates that Israel wasn't always exclusive and that there was space for 'Others' within the given guidelines.

Gillmayer-Bucher (2014:216) points out Jonah's story and the Book of Jonah's positivity towards the 'Other'. The Book of Jonah encourages its readers to follow the prophet's journey, meaning they will not be leaving Israel's traditions behind. This book deconstructs traditional prophets by silencing them and customary Israelite traditions. In this book, Jonah himself experiences YHWH as the ultimate 'Other' - but in turn, he understands that the relationship with $\mathrm{YHWH}$ is the only thing that matters. Boshoff et al. (2006) notes that the author of the Book of Jonah:

... wants people to understand that $\mathrm{YHWH}$, the God of Israel, is not only concerned with a small group of inhabitants of Judah, but all people. He is indeed the creator of heaven and earth, compassionate, forgiving, patient and full of love. He does not apathetically stand and stare when humans and beast perish, but is intensely affected by it. (p. 194)

Walsh (2014:123) on the other hand explains inclusivity via women in the Old Testament, and how women under the androcentric view are placed in odd positions of being both essential and 'Other'. Walsh (2014:129) points out that there is reference to quite a few stories of women as 'Others' living within the city wall or gate: Deuteronomy 22:15; Judges 9:53; Ruth 4:11; 2 Kings 6:26; 9:33; Songs 8:9-10; Esther 2:19; Ezekiel 8:14; 2 Maccabees 6:10; Tobit 11:16; Judith 8:33. Rahab who also lived within the city wall was 'Other' in three ways that she was female, enemy and a prostitute (Joshua 2:15). Because of her demographic situation, she is 'Otherised' by her own people, and consequently she found more empathy with the actual 'Other', the Israelite spies. Rahab's power as the 'Other' enabled to save her family by helping the Israelite spies - therefore, she is praised in Joshua for her fidelity in the God whom she did not yet know and was commended in Israel's memory (Walsh 2014:130). Walsh argues for Esther's power which enabled her a degree of freedom and agility and denied those who are regulated insiders (Walsh 2014:130). Walsh (2014) concludes:

All of these Othered woman - Rahab, Jael, Ruth, Jezebel, Vashti and Esther - exercise their power as Other inside the hegemonic power in place and manage to accomplish a great deal from their marginalized or outsider status. They all exercise their personal power from positions of vulnerability and, by doing so, expose the power dynamics at work. (p. 143)

\section{What is the truth?}

Brueggemann (2013:1) gives an interesting presentation of the truth that is not so easy to come by, specifically within biblical texts. Brueggemann (2013:2) did a study on David 
and pointed towards numerous narratives within the Hebrew Bible. These different narratives, offer distinct versions of the 'truth' about David. The most important truth that will be underlined in this study is the truth that comes from below, that is carried by non-experts, people without credentials. According to Brueggemann (2013:3), the truth that comes from below lives very near to actual concrete existence. Scott (1985:5) explains that the truth that was told by peasants, which was actually closely linked to the lived reality, was mostly kept hidden from the practitioners of official truth.

It is important to notice the power plays within biblical texts like the Old Testament, for official truth is carried by the urban elites of the dynasty and the temple, and eventually by the scribal class (Brueggemann 2013:3). Brueggemann (2013:5) describes truth as an army of metaphors. There is a power behind truth and Booth (1983:300) describes this as a 'secret communion' of the author and reader who share an understanding that is not apparent on the surface - it is the surface that is filled with presuppositions of power. Brueggemann (2013:6) warns that if the Bible is read only within the conventional historical criticism, 'we are likely to miss what is going on in the text as far as the Bible asserts truth that challenges power'. When we notice the irony (which goes together with power), we notice that the text speaks perforce and in a double dialect. Sharp (1986) describes irony as follows:

Irony is a performance of misdirection that generates aporetic interaction between an unreliable 'said' and a truer 'unsaid' so as to persuade us of something that is subtler, more complex, and more profound than the apparent meaning. Irony disrupts cultural assumptions about the narrative coherence that seems to ground tropological and epistemological transitions, inviting us into an experience of alterity that moves us toward new insight by problematizing false understanding. (p. 23)

Regarding irony/power, all the characters in the narrative must have a voice to be valid and truthful - and it is important to note that the most powerful voice is the holy voice which belongs to YHWH. According to Brueggemann (2013:37), social power becomes dislocated by truth when pain and the divine collude in subversion. Power is thus a system, which becomes uncontrolled when the holy factor intervenes.

Brueggemann (2013:150) notes that power, whenever and wherever it can, will present itself as a totalising system (as Israel's exclusivity), and: 'At a minimum, truth is the sneaky whisper and the resilient reminder that the totalizing claim of the regime is not true'. By this, it is always important to notice and see the power plays for what they are, and to notice that there are voices behind texts and from below that speak truth, break through the totalising system - like Ruth - and sometimes bring forth a new narrative of inclusion.

\section{Concluding remarks}

As Walsh (2014) says:

In a world where social identities are fashioned by systems of inclusion and exclusion, the text would seem to be positing, first, that Othering cannot be avoided, and second, that actions by the Other require a kind of shrewd prudence that can affect great events. (p. 142)

In this study, each subject discussed spoke for itself, but in due course the complexity of Israelite identity became evident, especially the fear of losing identity. It became clear that Israel 'Otherised' outsiders in terms of their fears, but in fact, this was unnecessary - the Book of Ruth is proof of this. The 'Other' has been widely discussed and mentioned more than a few times, and it appears that the 'Other', as well as the attitude of communities towards the 'Other', are not static; neither are the unspoken truths behind these texts and narratives.

Conferring to the texts that were discussed in this study, it became clear that with regard to the 'infinite Other' and in the light of hospitality, there are definite signs of inclusivity in certain Old Testament texts. These texts indicate that all humans are strangers on earth, hosted by YHWH. This basic concept was, at times, manipulated and they used the land as a power play. Presuppositions of socio-politics must be taken into consideration when biblical texts are used for universal exclusivity and 'Otherizing'.

The hope is that this study opens the minds of the interpreter (Snyman 2013:1-5) of the Old Testament text. It is important to know that the opening of arms reaches out towards the 'Other' as Volf (see Van Wyk 2017:1) explains and that the open gates are possible within the Old Testament, and even necessary. Inclusivity is the one subject which surpasses space and time and which has always been debated about, since biblical times, till now. By coming face-to-face with the infinitely 'Other', we learn our identity as the Israelites did in crucial times and this can be a valid example in present time - as demonstrated by ambassadors for inclusivity like Yolanda Dreyer.

\section{Acknowledgements Competing interests}

The authors declare that they have no financial or personal relationships which may have inappropriately influenced them in writing this article.

\section{Authors' contributions}

Both authors equally contributed to the research and writing of this article.

\section{References}

Ben Zvi, E., 2014, 'Othering, selfing, "Boundarying" and "Cross-Boundarying" as interwoven with socially shared memories: Some observations', in E.B. Ben Zvi \& D.V. Edelman (eds.), Imagining the other and constructing Israelite Identity in the early Second Temple Period, pp. 20-40, Bloomsbury T\&T Clark, London, UK.

Ben Zvi, E.B. \& Edelman, D.V. (eds.), 2014, Imagining the other and constructing Israelite Identity in the early Second Temple Period, Bloomsbury T\&T Clark, London, UK.

Berge, K., 2014, 'Categorical identities: "Ethnified otherness and sameness" - A tool for understanding boundary negotiation in the Pentateuch?', in E.B. Ben Zvi \& D.V. Edelman (eds.), Imagining the other and constructing Israelite Identity in the early Second Temple Period, pp. 70-88, Bloomsbury T\&T Clark, London, UK. 
Blyth, R.H., 1949, Haiku, Hokuseido Press, Tokyo.

Booth, W.C., 1983, The rhetoric of fiction, 2nd edn., Chicago University Press, Chicago

Boshoff, W., Scheffler, E. \& Spangenberg, I., 2006, Ancient Israelite literature in context, Protea Book House, Pretoria.

Botha, A. \& Dreyer, Y., 2013, 'Huwelik en huweliksrolle in Afrikaanse kultuur- en kerklike konteks', HTS Teologiese Studies/Theological Studies 69(1), 1-9. https://doi.org/10.4102/hts.v69i1.1965

Brett, M.G., 2014, 'Natives and immigrants in the social imagination of the holiness school', in E. B. Ben Zvi \& D.V. Edelman (eds.), Imagining the other and constructing
Israelite Identity in the early Second Temple Period, pp. 89-104, Bloomsbury T\&T Israelite Identity in
Clark, London, UK

Brueggemann, W., 2013, Truth speaks to power: The countercultural nature of scripture, Westminster John Knox Press, Louisville, KY

Camp, C.V., 2014, 'Gender and identity in the book of numbers', in E.B. Ben Zvi \& D.V. Edelman (eds.), Imagining the other and constructing Israelite Identity in the early Second Temple Period, pp. 105-121, Bloomsbury T\&T Clark, London, UK.

Cataldo, J.W., 2014, 'The other: Sociological perspectives', in E.B. Ben Zvi \& D.V. Edelman (eds.), Imagining the other and constructing Israelite Identity in the early Second Temple Period, pp. 1-19, Bloomsbury T\&T Clark, London, UK.

Clifford, J., 2009, 'Introduction: Partial truths', in P. Barry (ed.), Beginning theory: An introduction to literary and cultural theory, 3rd edn., pp. 1-26, Mancheste University Press, Manchester, CA.

Clines, D.J.A. (ed.), 2009, The concise dictionary of classical Hebrew, Sheffield Phoenix Press, Sheffield.

Cohn, R.L., 2014, 'Overcoming otherness in the Book of Ruth', in E.B. Ben Zvi \& D.V. Edelman (eds.), Imagining the other and constructing Israelite Identity in the early Second Temple Period, pp. 163-181, Bloomsbury T\&T Clark, London, UK.

De Villiers, G., 2013, 'Rut 4:18-22: “n Venster na Israel se verlede?"', Verbum et Ecclesia 34(2), Art. \#798, 1-8. https://doi.org/10.4102/ve.v34i2.798

De Villiers, G. \& Le Roux, J., 2016, 'The Book of Ruth in the time of the Judges and Ruth, the moabitess', Verbum et Ecclesia 37(1), Art. \#1587, 1-6. https://doi. org/10.4102/ve.v37i1.1587

Dreyer, Y., 2011, 'Women's spirituality and feminist theology: A hermeneutic of suspicion applied to "patriarchal marriage"', HTS 67(3), Art. \#1104, 1-5. https://doi.org/10.4102/hts.v67i3.1104

Edelman, D.A., 2014, 'YHWH's othering of Israel', in E.B. Ben Zvi \& D.V. Edelman (eds.) Imagining the other and constructing Israelite Identity in the early Second Temple Period, pp. 41-69, Bloomsbury T\&T Clark, London, UK.

Faculty of Theology, 2017, Theology centenary 2017, viewed 06 May 2017, from http://www.up.ac.za/faculty-of-theology

Geyser-Fouché, A., 2016, 'Exclusive language: The tool to empower and create identity', Verbum et Ecclesia 37(1), Art. \#1495, 1-9. https://doi.org/10.4102/ ve.v37i1.1495

Gillmayer-Bucher, S., 2014, 'Jonah and the Other', in E.B. Ben Zvi \& D.V. Edelman (eds.), Imagining the other and constructing Israelite Identity in the early Second Temple Period, pp. 182-218, Bloomsbury T\&T Clark, London, UK.

Glueck, N., 1927, Das Wort hesed im alttestamentlichen Sprachgebrauche als menschliche und göttliche gemeinschaftsgemäße Verhaltensweise, Alfred Töpelmann, BZAW, Berlin, danach im Verlag ... die Beihefte zur Zeitschrift für die alttestamentliche Wissenschaft (BZAW)

Hall, S., 1990, 'Cultural identity and diaspora', in J. Rutherford (ed.), Identity, community, culture, difference, pp. 222-237, Lawrence \& Wishart, London.

Harlow, D.C., Hogan, K.M., Goff, M. \& Kaminsky, J.S. (eds.), 2011, The 'Other' in Second Temple Judaism, study's in Honour of John J. Collins, William B. Eerdmans Publishing Company, Cambridge, MI, pp. 101-115.

Heckl, R., 2013, "'Deep is the well of the past": Reconsidering the origins of the exodus motif in its cultural context', Verbum et Ecclesia 34(2), Art. \# 806, 1-6. https://doi.org/10.4102/ve.v34i2.806

Hobbs, T.R., 2001, 'Hospitality in the first Testament and the "teleological fallacy"', Journal for the Study of the Old Testament 95, 3-30. https://doi.org/ 10.1177/030908920102600101

Howes, L., 2014, 'Judging the twelve tribes of Israel: Q22:28,30 in light of the Psalms of Solomon and the community rule', Verbum et Ecclesia 35(1), Art. \# 1320, 1-11. https://doi.org/10.4102/ve.v35i1.1320
Kaminsky, J.S., 2011, 'Israel's election and the other in Biblical, Second Temple, and Rabbinic thought', in D.C. Harlow, K.M. Hogan, M. Goff \& J.S. Kaminsky, (eds.), The Rabbinic thought', in D.C. Harlow, K.M. Hogan, M. Goff \& J.S. Kaminsky, (eds.), The
'Other' in Second Temple Judaism, study's in Honour of John J. Collins, pp. 17-30.

Keck, L.E., 1996, 'The premodern Bible in the postmodern world', Interpretation Journal 50, 130-141. https://doi.org/10.1177/002096439605000203

Klein, M., 2011, Envy and gratitude, and other works, Vintage Digital, New York.

Koenig, J., 1992, 'Hospitality', in D.N. Freedman (ed.), The anchor Bible dictionary, vol. III, pp. 299-301, Doubleday, NY.

Kooy, V.H., 1962, 'Hospitality', in G.A. Buttrick (ed.), The interpreter's dictionary of the Bible, vol. II, pp. 654, Nashville, Abingdon Press, NY.

Largen, K.J., 2010, 'Response to "the ethical horizon": Fidelity, hospitality, and justice', Journal of Ecumenical Studies 45, 433-439.

Le Roux, M. \& Dreyer, Y., 2013, 'Argeologie van homofobie: Boustene van mag', HTS 69(4), Art. \#2042, 1-8. https://doi.org/10.4102/hts.v69i1.2042

Levinas, E., 1989, 'Is ontology fundamental?', Philosophy Today 33(2), 121-129. https://doi.org/10.5840/philtoday198933218

Lim, T.H., 2011, 'How good was Ruth's Hebrew? Ethnic and linguistic otherness in the Book of Ruth', in D.C. Harlow, K.M. Hogan, M. Goff \& J.S. Kaminsky (eds.), The 'Other' in Second Temple Judaism, study's in Honour of John J. Collins, pp. 101-115

Loader, J.A., 2014, 'Understanding of failure and failure of understanding: Aspects of failure in the Old Testament', Verbum et Ecclesia 70(1), Art \#2657, 1-11. https://doi.org/10.4102/hts.v70i1.2657

Martin, L.R., 2014, 'Old Testament foundations for Christian hospitality', Verbum et Ecclesia 35(1), Art. \#752, 1-9. https://doi.org/10.4102/ve.v35i1.752

Meyer, E.E., 2011, 'The role of the Old Testament in a violent world', Verbum et Ecclesia 32(2), Art. \# 502, 1-8. https://doi.org/10.4102/ve.v32i2.502

Middlemas, J., 2011, 'Trito-Isaiah's Intra and internationalization. Identity markers in the Second Temple period', in O. Lipschits, G.N. Knoppers \& M. Oeming (eds.) Judah and the Judeans in the Achmaemenid period: Negotiating identity in an international context, pp. 105-125, Eisenbrauns, Winona Lake, IN.

Muir, J., 1997, 'Selected writings', D.C. Harlow, K.M. Hogan, M. Goff \& J.S. Kaminsky (eds.), The 'Other' in Second Temple Judaism, study's in Honour of John J. Collins, pp. 221-246, Penguin Putnam, USA.

Nederduitsch Hervormde Kerk van Afrika, 2017, Predikante, viewed 06 May 2017, from http://www.nhka.org/databasis/Predikante_list.php

Ogletree, T.W., 1985, Hospitality to the stranger: Dimensions of moral understanding, Fortress Press, Philadelphia, PA.

Reynolds, T.E., 2006, 'Welcoming without reserve? A case in Christian hospitality', Theology Today 63, 191-202. https://doi.org/10.1177/004057360606300205

Römer, T.C., 2013, 'Yhwh, the Goddess and Evil: Is "Monotheism" an adequate concept to describe the Hebrew Bible's discourse about the God of Israel?', Verbum et Ecclesia 34(2), Art. \#841, 1-5, https://doi.org/10.4102/ve.v34i2.841

Scott, J.C., 1985, Weapon of the weak: Everyday forms of peasant, resistance, Yale University Press, New Haven, CT.

Sharp, C.J., 1986, Irony and meaning, Indiana University, Bloomington, IN.

Snyman, S.D., 2013, 'Some preliminary thoughts on epistemological transformation and the study of the Old Testament', Verbum et Ecclesia 34(3), Art. \#794, 1-5. https://doi.org/10.4102/ve.v34i2.794

TEO, 2009, Apartheid in Kerk en in Politiek - Johan Buitendag 2009, viewed 06 May 2017, from http://teo.co.za/apartheid-in-kerk-en-in-politiek/

Touraine, A., 2007, 'Sociology after sociology', European Journal of Social Theory 10(2), 184-193. https://doi.org/10.1177/1368431007078894

Van Wyk, T., 2017, “n Voortgaande appèl tot inklusiwiteit', Blitspos@NHK, 23 March, p. 1.

Walsh, C., 2014, 'Women on the edge', in E.B. Ben Zvi \& D.V. Edelman (eds.), Imagining the other and constructing Israelite Identity in the early Second Temple Period, pp. the other and constructing Israelite Identity in
$122-143$, Bloomsbury T\&T Clark, London, UK.

Wetter, A.M., 2014, 'Ruth: A born-again Israelite? One woman's journey through space and time', in E.B. Ben Zvi \& D.V. Edelman (eds.), Imagining the other and constructing Israelite Identity in the early Second Temple Period, pp. 144-162, Bloomsbury T\&T Clark, London, UK.

Zizek, S., 2008, In defence of lost causes, Verso, London, UK. 